\title{
The Biology of Thecaphora frezii Smut and Its Effects on Argentine Peanut Production
}

\author{
Luis Ignacio Cazón, Juan Andrés Paredes and \\ Alejandro Mario Rago
}

Additional information is available at the end of the chapter

http://dx.doi.org/10.5772/intechopen.75837

\begin{abstract}
Thecaphora frezii was first reported in 1962 in wild peanut from Aquidauana, Mato Grosso do Sul, Brazil. In Argentina, it was first detected in 1995 in commercial crops from the central-northern area of Córdoba province. The fungus can survive in the soil as teliospores. When peanut gynophore penetrates the soil, their exudates disrupt telial dormancy; T. frezii penetrates and colonizes the tissues and replaces the cells with teliospores. Since its first report, peanut smut prevalence has gradually increased in peanut areas to reach a $100 \%$ in 2012. Currently, it is the most important peanut disease in Argentina, not only for its destructive power on crop but also for its quick spread throughout the growing region of Córdoba and the lack of effective tools for its management. It is important for additional research to find effective agronomical practice that reaches high control efficiencies. The collaboration of all those involved in Argentinian peanut production systems is necessary for the management of peanut smut to be successful.
\end{abstract}

Keywords: peanut smut, teliospores, peg, basidiospores, phytopathology

\section{Introduction}

Peanut is an herbaceous plant from South America. Its origin is located specifically in southeastern Bolivia and northwestern Argentina, where its parental species are found in wild habits [1]. In 1753 the cultivated species of peanut was classified as Arachis hypogaea L. in two subspecies, hypogaea and fastigiata [2]. Arachis hypogaea belongs to the family Leguminosae, subfamily Papilionoidea, and gender Arachis [3]. Peanut is an annual plant, and its growth habits are described as bunch, decumbent, or runner. The bunch types can 
reach $40 \mathrm{~cm}$ in height. They have an upright growth habit with flowering on the main stem and lateral branches. Runner types can reach $120 \mathrm{~cm}$ in diameter, and they are considered to have a prostrate growth habit and do not flower on the main stem. Decumbent varieties have an intermediate growth habit between a runner and bunch [4]. Peanut has vegetative and reproductive stages. The vegetative stage involves germination and formation of stems and leaves. Reproductive stage goes from flowering (R1) to the obtaining of overripe fruit (R9) $[5,6]$. The flowering process covers almost $80 \%$ of the peanut life cycle and overlaps with the fruiting period. After the flower fertilization, the cells located under the receptacle divide rapidly, giving rise to the gynophore or "peg." Gynophore grows toward the ground by stimulation of the light, carrying at its end the ovary protected by a layer of lignified cells [7]. Once introduced into the soil, the elongation stops, and the fruit begins to develop. This requires darkness, mechanical stimulation of the medium, humidity, and the presence of calcium [1]. In Argentina, peanut represents one of most important local economies. More than $92 \%$ of Argentine peanut production and processing is in the center of the country, mainly in the province of Córdoba. In this region, more than 12,000 jobs are directly or indirectly related to peanut production [8, 9]. In 2016/2017, peanut was cultivated over 328,600 ha, producing a total of $1.17 \mathrm{MT}$ of peanut and an average yield of $3.69 \mathrm{~T} /$ ha. Peanut industry is characterized as an "exporter industry" in Argentina. More than $80 \%$ of Argentine production is exported to the European Union (mainly the Netherlands, Germany, England, Spain, Italy, Greece, and France) and other countries such as the USA, Canada, China, and India. All these facts show that peanut industry is not only important to Argentina but also the world peanut market [10]. In Argentina, during the 1980s, peanut production changed to adapt to the demand of the international market for edible peanut. New cultivars were used, passing from bunch-type cultivars to runner types. However, the prevailing climatic conditions were conducive for the development of soilborne fungal diseases [11, 12]. Therefore, peanut production was moved to more southern areas of Cordoba in the early 1990s to avoid the consequences of the production issues in the northern region [13]. During this migration process, emerged peanut smut caused by Thecaphora frezii. It was first detected in commercial peanut in the northern producing areas in Córdoba province and then established on the central region where the main grain processing industries are located [14]. Currently, Argentina is the only country that has reported peanut smut in commercial crops. Both Bolivia and Brazil, however, have only reported cases of smut in wild peanuts [15-17]. T. frezii was first reported in 1962 in wild peanut samples from Aquidauana, Mato Grosso do Sul, Brazil [15, 18] (Figure 1). In that time, fungus was classified based on disease symptoms and morphology of teliospores. 51 years later this classification was confirmed using molecular tools [19, 20]. In Argentina, T. frezii was first detected in commercial crops of peanuts from the central-northern area of Córdoba province: Pampayasta $\left(32^{\circ} 15^{\prime} 07^{\prime \prime S} 63^{\circ} 39^{\prime} 20^{\prime \prime} \mathrm{W}\right)$, Villa Ascasubi $\left(32^{\circ} 10^{\prime} 00^{\prime \prime} \mathrm{S} 63^{\circ} 53^{\prime} 00^{\prime \prime} \mathrm{W}\right)$, and Ticino $\left(32^{\circ} 41^{\prime} 25^{\prime \prime} \mathrm{S} 63^{\circ} 23^{\prime} 14^{\prime \prime} \mathrm{W}\right)$ [14]. By this time, the presence of affected pods was more frequent year by year in different plots across the peanut area, to finally being found in all production fields in the 2011/2012 growing season [21, 22]. 2 years later, the prevalence was $100 \%$ in Argentinian production area, including Salta, Jujuy, La Pampa, and San Luis [23]. During the last 10 years, this disease has caused significant decreases in yield production in Argentina, resulting in 51\% losses in some locations [13, 21, 22, 24]. 


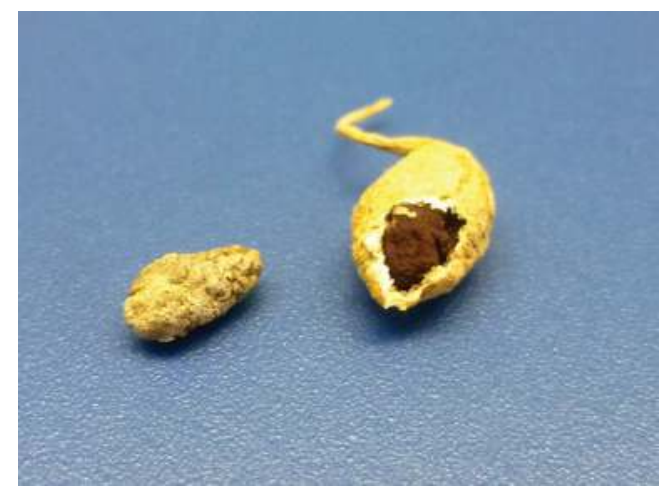

Figure 1. Seed and wild peanut pod totally damaged by smut (mass of teliospores replacing the grain tissue).

\section{Peanut smut symptoms and disease assessment}

The smut symptoms are very characteristics on peanut and easy to identify. Affected pods shows hypertrophy and spongy consistence when the infection is highly severe. The wall of pods tends to thin, and the grains inside could be totally or partially transformed in a reddish-brown smutted mass (Figure 2). According to the symptoms, it is possible to assess the disease in mature pods (R8) from a given field. In this stage, the disease expression is very clear [17]. There are two parameters to consider when quantifying the disease intensity in affected fields: in terms of incidence and severity. The first is the proportion of infected pods out of a total sample, and the second is the proportion of damaged pod tissue. Disease severity can be estimated using a diagrammatic scale representing five different severity levels [25]. Ordinal levels of 0 , healthy pods; 1 , normal pod with a small sorus in single kernel; 2 ,

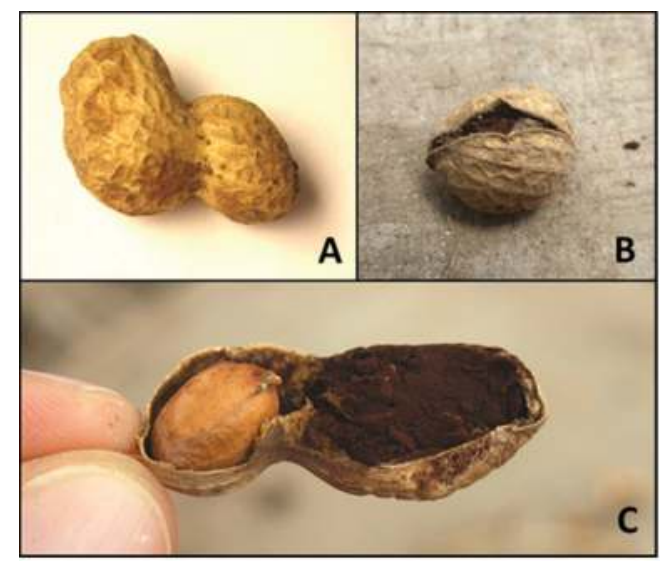

Figure 2. Peanut pods affected by smut. A: Hypertrophied pod due to smut. B: Totally smutted pod. C: Partially smutted pod. 


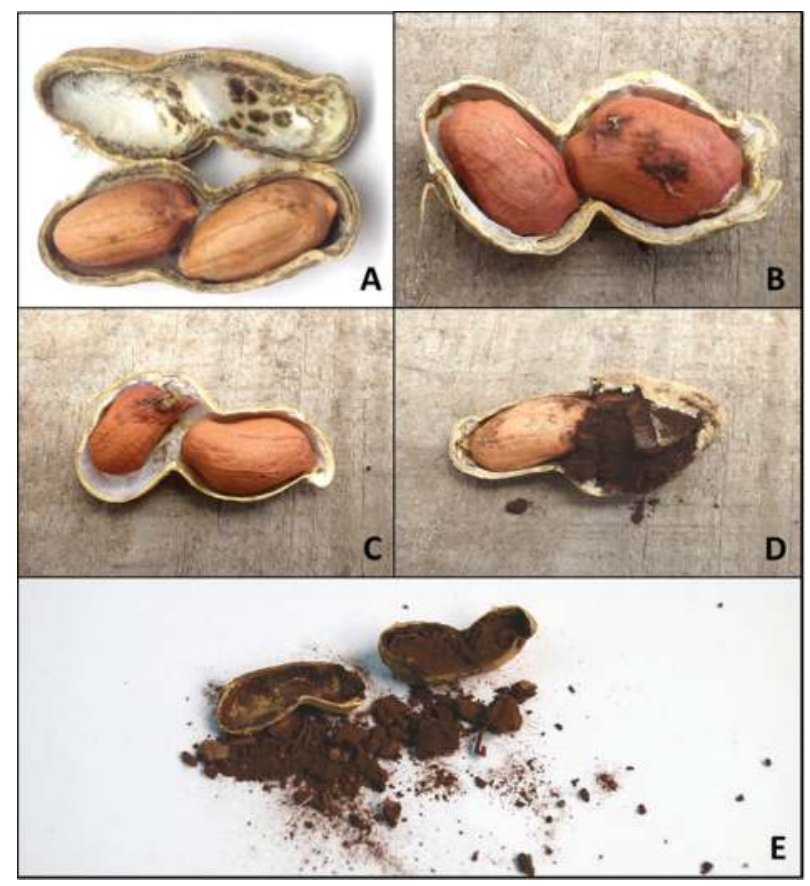

Figure 3. Peanut smut severity scale. A: level 0. B: level 1. C: level 2. D: level 3. E: level 4.

deformed or normal pod with half of the kernels affected; 3, deformed pod and a completely smutted kernel; and 4, deformed pod, two completely smutted kernels (Figure 3). Combining both parameters, incidence and severity, it is possible to calculate "intensity" [26]. For disease assessment, [27] surveyed different fields in Córdoba production area in two consecutives growing seasons (2015/2016 and 2016/2017) and determined the amount of samples according the regional average incidence. They concluded that regions with low incidence values need to be assessed using the highest amount of samples than regions with high incidence values. It is important to emphasize that the evaluation of the disease in the field is a tool to know the final sanitary status. To avoid high levels of disease, it is necessary to adopt other management strategies prior to harvest.

\section{The pathogen life cycle}

T. frezii can survive in the soil as teliospores; those are resistant structures that enable the fungus to be infective for many years in the soil. Ref. [28] studied the infection capacity of teliospores in the field, and they observed that it can be infective for more than 4 years. Smut spores are brown, 20-40 $\mu \mathrm{m}$ in size, and have an echinulate surface [29]. They are thick-walled structures that enable the fungus to survive in different environmental conditions (Figure 4). 
When peanut pegs penetrate the soil, their exudates promote spore germination and initiate local infections $[30,31]$. The process of teliospore germination includes the formation of a probasidium, followed by a basidium which forms basidiospores. When basidiospores germinate, compatible haploid germ tubes fuse and produce a dikaryotic infective mycelium that penetrate the peanut gynophore in the soil, colonize the tissues, and replace the cells with reddish-brown teliospores [32,33]. When the affected mature pods open, start the dispersion process (Figure 5). There are three important dispersion methods: wind, machinery and seeds. During the harvest activities, a cloud of dust is generated. Teliospores are transported by wind to adjacent fields. According to the Ref. [34], teliospores can travel at least $400 \mathrm{~m}$ depending on the wind rate. Peanut processing plants are one of the most important sources of teliospores. In the shelling process, a totally smutted pods release millions of spores that are transported by wind. Long-distance dispersion is attributed to infested machinery and infected seeds. Infested machinery can carry teliospores from one infected field to another located in other provinces or bordering countries [17]. Using the seeds, the pathogen can disperse even to other continents through exportation activities [35]. Teliospores can infest externally asymptomatic seeds or in small lesions that are not detected in the process of selection of seeds $[31,36]$.

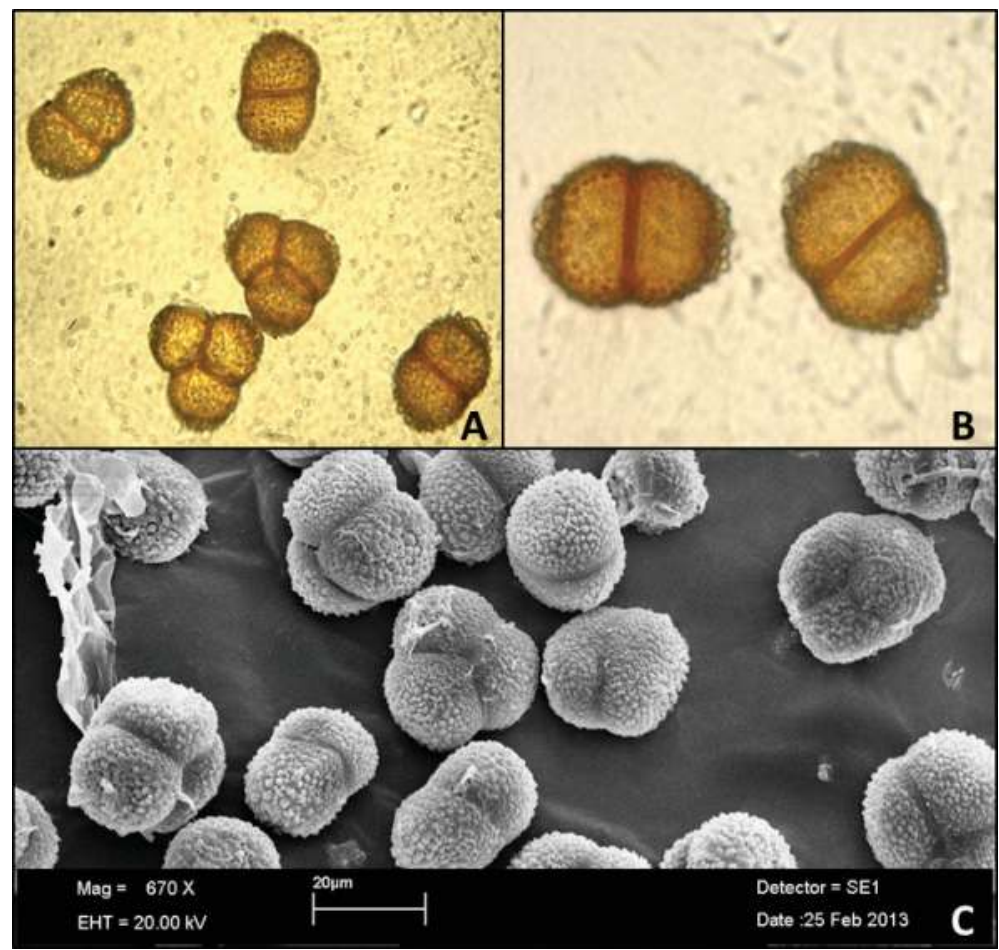

Figure 4. Teliospores of Thecaphora frezii. A, B: Teliospores observed under light microscope 40X. C: Scanning electron micrographs of multicellular teliospores. 


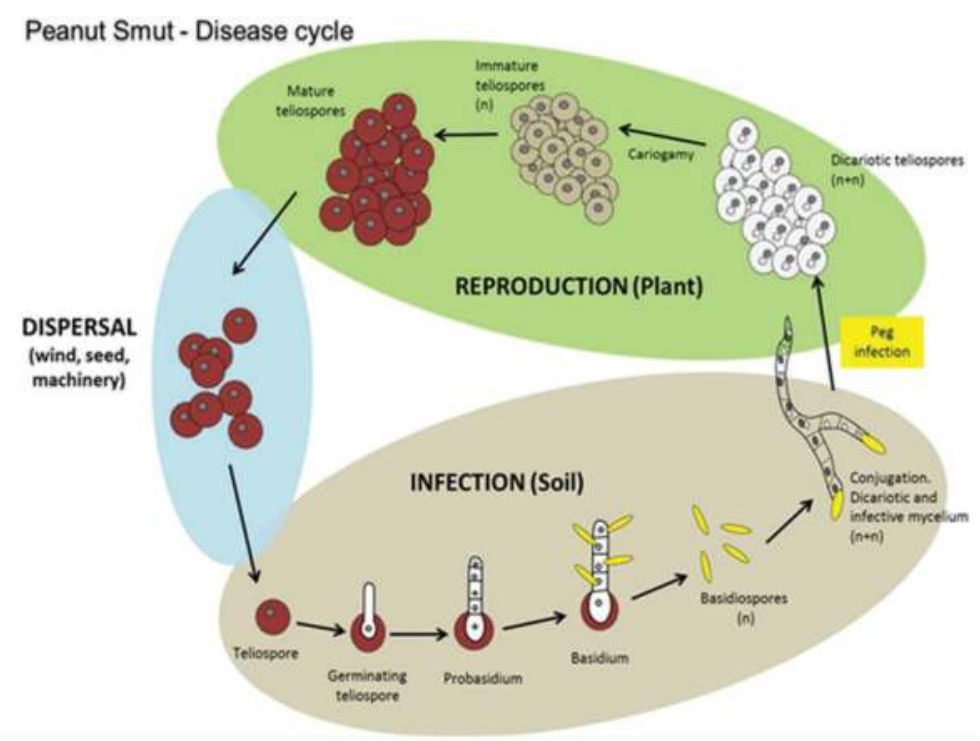

Figure 5. Peanut smut disease cycle [17].

\section{Distribution of the disease and yield losses}

Peanut smut is distributed across the entire production area in Argentina [22]. It was first reported in the north of Córdoba [14] and from this region began to expand. The first survey was performed in 2008 [31]. The data show that the prevalence was $10 \%$ in 1997 and increased to $24 \%$ in the next 10 years. In 2012, the prevalence was $100 \%$ in Córdoba, and 2 years later, the prevalence was $100 \%$ in Argentina peanut area, including Salta, Jujuy, La Pampa, and San Luis [22, 23]. To determine the yield losses in Córdoba province, [37] assessed peanut smut in 40 fields from peanut area in 2015/2016 growing season. The data show yield losses of 27.419 tons (USD 14.151.800), representing 3.15\% of the total production. In some fields, yield losses of $35 \%$ with incidence values to $52 \%$ could be observed. The most affected region was in the north of Córdoba peanut area, with average incidence of $17 \%$ and yield losses of 21.894 tons. They observed that disease intensity decreases southward. This gradient is because the new production areas are there, away from processing plants, and a much smaller history of peanut crop than north (Figure 6). There are some studies about the yield loss estimation. Peanut smut incidence above $14 \%$ can be considered as a damage threshold, and it is estimated that $1 \%$ increase in incidence can correspond to a $1.2 \%$ decrease in yield. The loss estimation in field with low inoculum density is erratic, whereas the correlation was high between the losses and the $n^{\circ}$ teliospores/gr. of soil in field with high inoculum density [38]. In Ref. [37], peanut smut was evaluated in different fields, and a linear relationship $\left(R^{2} 0.92-0.97\right)$ between estimated yield losses and disease intensity was observed. 


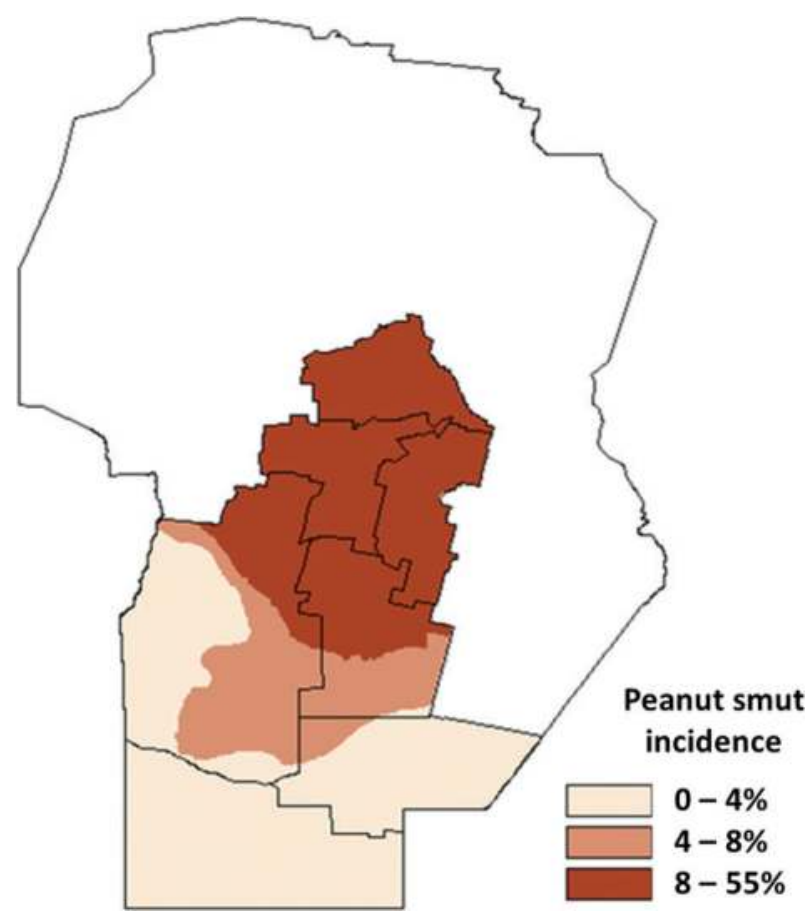

Figure 6. Gradient of disease incidence decreasing southward. Different colors represent peanut smut incidence found in different zones [37].

\section{Teliospore detection}

Detection and quantification of spores, both in soil and seeds, represent an important tool to epidemiological management of disease. Peanut smut is considered a monocyclic disease since there is no secondary inoculum produced in the same growing season and polyetic since annual inoculum accumulation affects subsequent seasons [17]. Knowing the amount of teliospores in the soil, it is possible to predict the incidence of the disease in the harvest [24]. On the other hand, by determining the amount of inoculum transported by seeds, it is possible to identify the contribution of teliospores to the field, which increases the probability of occurrence of the disease in future peanut plantations. In 2008, the detection of teliospores from soil samples using a microscope was performed [31]. The same technique was also employed to quantify spores on peanut seeds [39]. Using molecular methods, in 2014, a PCR protocol to detect teliospores was described. This begins with washing off a kernel sample with distilled water, separating supernatant water from kernels and extracting fungal DNA from the obtained pellet. PCR amplification is then performed using specific primers designed for $T$. frezii. This method is highly sensitive and can detect the presence of ten teliospores $\left(10^{-4} \mathrm{pg}\right.$. DNA) from a sample of 400 kernels. Its specificity is achieved by using primers that do not hybridize with the DNA of other seed-borne pathogens, such as Sclerotinia minor, S. 
sclerotiorum, Sclerotium rolfsii, or Fusarium solani [40,41]. These primers can be adapted for teliospore quantification using real-time PCR (RT-PCR), with a detection sensitivity of two teliospores in a sample of 400 seeds [42]. The development and use of detection techniques are important, because Argentina is the only country in South America that has reported this disease, hence the importance of implementing effective peanut smut management strategies that can minimize yield losses and contaminations of exportation products $[8,35,43]$.

\section{Peanut smut management}

In the last years, various researchers have been studying different strategies for peanut smut control. Among them are the development of resistant cultivars, cultural practice, chemical and biological control.

\subsection{Host resistance}

High levels of infestation in the soils of the northern Córdoba peanut area and the lack of commercial fungicide that provides high disease control make the genetic resistance the main tool for an integrated management approach [17,44]. Currently, 100\% of cultivars widely planted are susceptible, which have favored T. frezii to quickly spread throughout the growing region of Córdoba $[45,46]$. There is differential response of some cultivars against peanut smut. Pepe ASEM-INTA cultivar had 34\% disease incidence and Colorado Irradiado-INTA $71 \%$ under favorable conditions [47]. Granoleico, the most widely distributed cultivar on Córdoba peanut area, shows incidence of 50\% in high infested soil [27, 37, 47-49]. In 2011, it was reported that wild species Arachis correntina and Arachis valida show resistance to T. frezii [32]. Recently, INTA released a new cultivar, Ascasubi Hispano, with high tolerance to peanut smut (less than $2 \%$ of affected pods in high infested soil), but is not high-oleic cultivar. Among the tools used to facilitate the transfer of resistance are the molecular methods. In 2015, molecular markers associated with the tolerance to peanut smut were found [50]. Marker-assisted selection represents an important tool for breeding programs, as it would save time and money in the development of smut-tolerant cultivars [51]. There are cultivars highly tolerant to peanut smut in the final stages of evaluation [52]. This material would also be useful to prevent the spread of the pathogen to new areas of production [17]. Another aspect to consider is the ability of T. frezii to adapt to new cultivars. Cazón (unpublished) developed molecular markers to study the temporal variation of $T$. frezii isolates from different years and locations. If the rate of genetic variation of the pathogen is high, the resistance of the new cultivars against smut could be broken. Because of this, it is necessary that breeding programs continue to develop peanut smut-resistant cultivars.

\subsection{Cultural practice}

These strategies were focused on the reduction of initial inoculum. For peanut smut management, crop rotation schemes of more than 3 years without peanuts showed low T. frezii teliospore density in soil [53]. In addition, peanut crops preceded by corn exhibited lower 
incidence of peanut smut than those preceded by soybean [35]. Different authors used deep tillage to burying teliospores $20 \mathrm{~cm}$ of depth reducing disease incidence, since peanut pods develop at a planting depth between 5 and $7 \mathrm{~cm}[54,55]$. Other practices were focused on modifying the soil chemical and physical properties. The objective is making the soil suppressive to $T$. frezii. The use of gypsum $\left(\mathrm{CaSO}_{4}\right)$ and dolomite to modify the $\mathrm{pH}$ of soil can contribute to a partial reduction of peanut smut intensity [21]. Phosphate-containing products were assessed to reduce the smut damage. This provided a control efficiency of $16 \%$ reduction in peanut smut intensity [56, 57].

\subsection{Biological control}

This area is not highly developed to peanut smut management. There are only some experiments done that used bioformulations based on Trichoderma harzianum. Control efficiency reaches $24 \%$ in incidence and $25 \%$ in severity $[58,59]$. Researchers of IPAVE-CIAP-INTA have assessed the bioformulations based on Bacillus subtilis in different doses combining with soil amendments. Therefore, cultural practices and biological control still need to be studied in greater depth for sustainable and economic management of the disease.

\subsection{Crop protection fungicides}

The first experiences were performed in vitro using seed treatment fungicides. Teliospores were germinated using leaves and fruit extracts with the addition of PDA medium ( $39 \mathrm{gr} / \mathrm{l})$. Later, a single colony was picked in media with different fungicides and evaluated the mycelial growth (Figure 7). All tested fungicides were effective, but the result could not be extrapolated to the field [33]. This is because the infection process occurred when fungicides from seed treatments have lost their protective effects [17]. The highest control efficiencies were achieved using crop protection fungicides in soil-directed applications. This is because the infective processes occur in the soil, where teliospores infect the gynophore [25, 31, 44]. Refs. [37, 60-62] show that these strategies were more effective at controlling peanut smut than leaf applications. They performed night spraying because in this moment, peanut leaves fold up, and the soil surface is easily reached [17, 63, 64]. Using strobilurin/triazole mixtures like

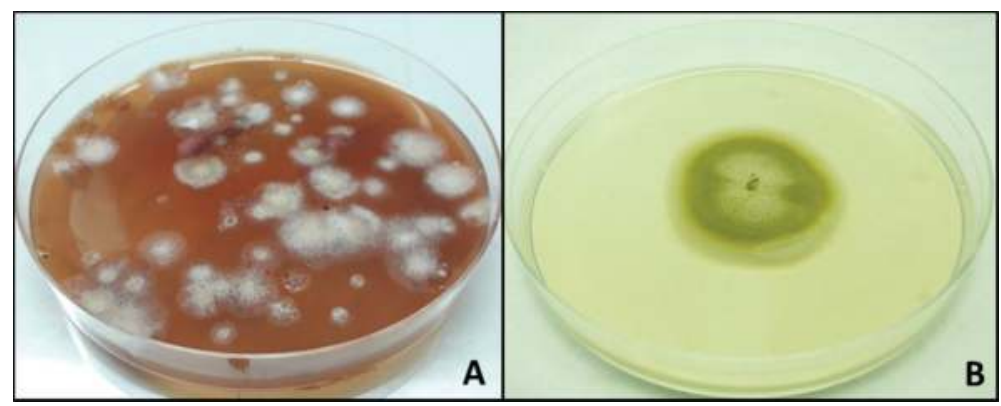

Figure 7. Colonies of T. frezii. A: Teliospores germinated in PDA medium ( $39 \mathrm{gr} / \mathrm{l})$ composed by fruit extracts. B: T. frezii micelial growth of 7 days old plated on PDA medium ( $39 \mathrm{~g} / \mathrm{l})$. 


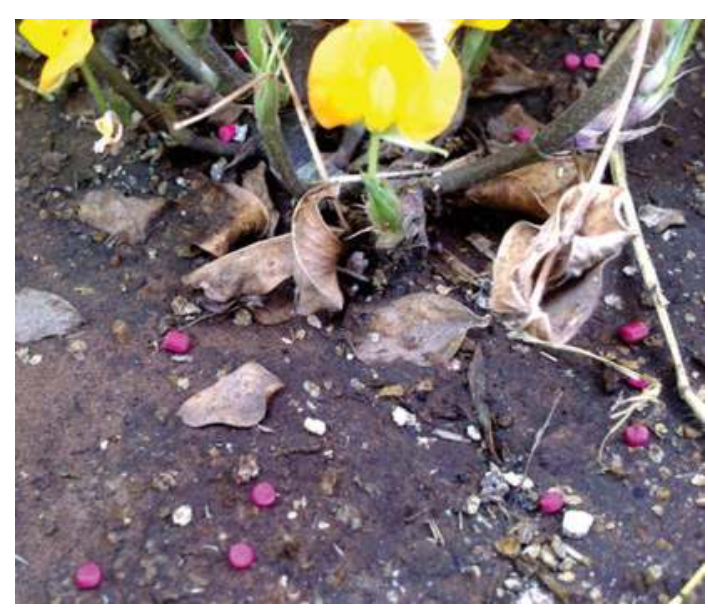

Figure 8. Experimental granulate fungicide applied on peanut.

picoxystrobin + cyproconazole, control efficiencies reach $47 \%$ at a rate of $900 \mathrm{cc} / \mathrm{ha}$ or $1000 \mathrm{cc} / \mathrm{ha}$ in two applications in R2 (beginning peg) [65] and 10 days [17, 47]. An experimental granular fungicide with a slow release for longer protection during crop pegging was assessed [26]. Control efficiency reached $42 \%$ in incidence if the granulate is applied at flowering (Figure 8). Another study performed in INTA affirms that using high dose and night spraying for the first late leaf spot (Cercosporidium personatum) application ensures a 35\% smut incidence reduction [37]. Control efficiencies close to $50 \%$ for peanut smut is an acceptable value, so accompanied by efficient molecules, correct dose and good times, and application technologies, chemical control could contribute to integrated disease management [17].

\section{Conclusions}

Argentina is the only country that has reported the disease in cultivated peanuts. Currently, it is the most economically important peanut disease in the country. This is due to the characteristics of the pathosystem. These represent an important prejudice since the peanut industry has clearly agroexporting characteristics. The alert generated by smut in the producing countries is mainly due to the destructive power of the disease in the crop but also to the lack of efficient strategies to control the disease and the speed with which the pathogen spreads throughout the Argentinean peanut area in a short time. There were many factors that contributed to the spread of the pathogen. Among them are the low diversification of cultivars used in recent years, the lack of crop rotations and the use of nonspecific fungicides. One of the most important facts is related to the increase of production scale in the 1990s. Many small-sized growers that used to harvest their own seeds were removed from the production system since they could not afford the costs of change of scale. Big growers produced and processed peanuts on a larger scale which included both healthy and diseased fields. This encouraged seed contamination and spread of the pathogen spores. Based on the current 
understanding about the pathosystem and effectiveness of various techniques described, it is possible to recommend disease management tactics to minimize yield losses:

i. The use of pathogen-free seed: This is important to not increase the amount of teliospores in the soil.

ii. Plant peanuts in fields that have low inoculum density of T. frezii teliospores: In Córdoba province the healthiest area is in the south, to correspond to new production areas.

iii. The fields chosen to cultivate peanut are not to be close to peanut processing factories: Peanut processing plants are the most important sources of teliospores. Those teliospores can be transported by wind to adjacent fields.

iv. Spray fungicide mixtures including strobilurins and triazoles: azoxystrobin and cyproconazole are the most effective fungicides. Soil-directed spraying at the beginning of crop pegging and 7 days after.

It is important that additional research will be focused in determining the most effective agronomical practice with the most suitable application technologies that reach high control efficiencies. It is necessary that the recommended agricultural practices will be implemented in an entire peanut area, like a regional management. The development of molecular tools is important to facilitate the transfer of resistance to new cultivars and speed up the processes of obtaining varieties with good agronomic characteristics. The collaboration of all those involved in Argentinian peanut production systems is necessary for the management of peanut smut to be successful.

\section{Acknowledgements}

We wish to thank Fundación Maní Argentino for providing resources for many research experiments cited in this work.

\section{Conflict of interest}

All authors declare no conflict of interest about this publication.

\section{Author details}

Luis Ignacio Cazón ${ }^{1 *}$, Juan Andrés Paredes ${ }^{1}$ and Alejandro Mario Rago ${ }^{1,2}$

*Address all correspondence to: cazon.ignacio@inta.gob.ar

1 Instituto de Patología Vegetal, CIAP - INTA, Córdoba, Argentina

2 Facultad de Agronomía y Veterinaria, UNRC, Córdoba, Argentina 


\section{References}

[1] Fernandez EM, Giayetto O, Cholaky Sobari L. Crecimiento y desarrollo. In: Fernandez E, Giayetto O, editors. El cultivo de maní en Córdoba. Departamento de Imprenta y Publicaciones de la UNRC; 2006. pp. 73-88

[2] Linneo C. Salvius, London: Species Plantarum: 1753;(2):741

[3] Lavia GI. Karyotypes of Arachis palustris and A. praecox (section Arachis), two species with basic chromosome number $X=9$. Cytologia. 1998;63:177-181

[4] Krapovickas A, Gregory WC. Taxonomía del género Arachis (Leguminosae). Bonplandia. 1994;8:1-186

[5] Maní CL. Influencia de los factores climáticos sobre el crecimiento-desarrollo, morfología, fotosíntesis, componentes del rendimiento, composición ácido graso del aceite y producción. Mimeo: Departamento de Producción Vegetal, Facultad de Agronomía y Veterinaria, Universidad Nacional de Río Cuarto; 1984. p. 125

[6] Fernández A, Krapovickas A. Cromosomas y evolución en Arachis (Leguminosae). Bonplandia. 1994;8:187-220

[7] Ashley JM. Groundnut. In: Golsworthy PR, Fisher NM, editors. Chichester (UK): The Physiology of tropical field crops; 1984. pp. 453-494

[8] de Maní CA. Outlook del Cluster Manisero Argentino. Fundación Maní Argentino. Córdoba, Argentina; 2013. p. 16

[9] Fiant S, Alonso C, Fontana T, Spinazzé C, Costero D, Agusto G, Pérez C, Bonvehi L, Fuentes L, Meriggiola P. Caracterización de la producción de maní. Campaña 2012/2013. $28^{\circ}$ Jornada Nacional de Maní. Córdoba: General Cabrera; 2013. pp. 24-25

[10] de Cereales de Córdoba B. Estimación de la producción. Bolsa de Cereales de Córdoba. Julio de 2016. Córdoba, Argentina; 2016. p. 15

[11] Marinelli A, March G, Lenardon S. Enfermedades del maní. In: Fernandez E, Giayetto O, editors. El cultivo de maní en Córdoba. Departamento de Imprenta y Publicaciones de la UNRC; 2006. pp. 179-208

[12] Oddino. Aspectos biológicos y epidemiológicos de la podredumbre parda de la raíz causada por Fusarium solani [tesis]. Río Cuarto, Córdoba, Argentina. Universidad Nacional de Río Cuarto. Facultad de Agronomía y Veterinaria; 2007

[13] March G, Marinelli A. Enfermedades y sistema productivo. In: March G, Marinelli A, editors. Enfermedades de maní en Argentina. Córdoba: Biglia Impresores; 2005. pp. 1-11

[14] Marinelli A, March G, Rago A. El carbón del maní Thecaphora frezii sobre Arachis hypogaea L. $7^{\circ}$ Congreso de Micología y $17^{\circ}$ Jornadas Argentinas de Micología. Rosario - Santa Fe; 1995.134 p

[15] Carranza J, Lindquist J. Thecaphora frezii, parasita de Arachis sp. Boletín de la Sociedad Argentina de Botanica. 1962;10:11-18 
[16] Soave J, Bianco C, Burgoa R, Montaño R, Rago A, Cazón I, Paredes JA, Buteler M, Faustinelli P, Soave S, Moresi A, Torres D, Oddino C. Primera detección de carbón del maní (Thecaphora frezii) en Bolivia. $3^{\circ}$ Congreso Argentino de Fitopatología. Tucumán, Argentina; 2014. $211 \mathrm{p}$

[17] Rago AM, Cazón LI, Paredes JA, Edwards Molina JP, Conforto C, Bisonard EM, Oddino C. Peanut Smut: from an emerging disease to an actual threat to Argentine peanut production. Plant Disease. 2017;101(3):400-408

[18] Fávero AP. Cruzabilida de entre espécies silvestres de Arachis visando à introgressão de genes de resistência a doenças no amendoim cultivado [tesis]. Universidade de São Paulo; 2004. 165 p

[19] Conforto C, Cazón I, Fernandez F, Marinelli A, Oddino C, Rago A. Caracterización molecular de la región D1-D2 de la subunidad ribosomal mayor (DNAr 5' LSU) de Thecaphora frezii, agente causal del carbón del maní. $27^{\circ}$ Jornada Nacional de Maní. General Cabrera Córdoba; 2012. pp. 19-20

[20] Conforto C, Cazón I, Fernandez F, Marinelli A, Oddino C, Rago A. Molecular sequence data of Thecaphora frezii affecting peanut crops in Argentina. European Journal of Plant Pathology. 2013;137(2):663-666

[21] Bonessi F, Rago AM, Marinelli AD, March GJ, Cazón LI, García J, Oddino CM. Efecto de la fertilización sobre la intensidad del carbón del maní. $26^{\circ}$ Jornada Nacional del Maní. General Cabrera, Córdoba; 2011. pp. 63-64

[22] Cazzola N, Gateu M, March G, Marinelli A, García J, Rago A, Oddino C. Intensidad y pérdidas ocasionadas por carbón del maní según regiones de producción. $27^{\circ}$ Jornada Nacional del Maní. General Cabrera. Córdoba; 2012. pp. 34-35

[23] Cazón LI, Paredes JA, Edwads Molina JP, Bisonard EM, Conforto EC, Rago AM. Biology of Thecaphora frezii and peanut smut effects on the production in Argentina. The smut problem in South America. In: Ninth international conference of the peanut research community. Advances in Arachis through genomics and biotechnology, March, 14-17. Córdoba, Argentina; 2017

[24] Oddino C, Marinelli A, March G, García J, Tarditi L, D’Eramo L, Ferrari S. Relación entre el potencial inóculo de Thecaphora frezii la intensidad de carbón del maní y el rendimiento del cultivo. 25 Jornada Nacional del Maní. General Cabrera, Córdoba; 2010. pp. 24-26

[25] Astiz Gasso M, Leis R, Marinelli A. Evaluación de incidencia y severidad del carbón de maní (Thecaphora frezii) en infecciones artificiales, sobre cultivares comerciales de maní. $1^{\circ}$ Congreso Argentino de Fitopatología; 2008. 161 p

[26] Paredes JA, Edwards Molina JP, Cazón LI, Bisonard EM, Rago AM. Alternativas tecnológicas de aplicación de fungicidas para el control de Thecaphora frezii. $29^{\circ}$ Jornada Nacional del Maní. General Cabrera, Córdoba; 2014. pp. 49-50

[27] Paredes JA, Cazón LI, Bima M, Kearney MI, Nicolino JM, Rago AM. Protocolo de toma de muestras y evaluación para un correcto relevamiento del carbón del maní. $32^{\circ}$ Jornada Nacional de Maní. 21 de septiembre. General Cabrera, Córdoba; 2017. pp. 59-61 
[28] Cazón LI, Paredes JA, Bisonard EM, Rago AM. Capacidad de infección de Thecaphora frezii en el tiempo. $31^{\circ}$ Jornada Nacional de Maní. 22 de septiembre. General Cabrera, Córdoba; 2016. $52 \mathrm{p}$

[29] Marraro Acuña F, Cosa M, Wiemer A. Carbón del maní: Histología, incidencia y severidad. $28^{\circ}$ Jornada Nacional de Maní. General Cabrera. Córdoba; 2013. pp. 26-27

[30] Astiz Gassó MM, Marinelli A. Cultivo in vitro de Thecaphora frezii (ustilaginales), carbón de maní (Arachis hypogea). 29 Jornadas Argentinas de Botánica \& $15^{\circ}$ Reunión Anual de la Sociedad Botánica de Chile; 2003. 256 p

[31] Marinelli A, March G, Oddino C. Aspectos biológicos y epidemiológicos del carbón del maní (Arachis hypogaea L.) causado por Thecaphora frezii Carranza \& Lindquist. Ağrı. 2008;25(1):1-5

[32] Astiz Gassó MM, Leis R, Marinelli AD. Evaluación de tolerancia de germoplasma de maní (Arachis spp.) para el manejo del carbón (Thecaphora frezii). $26^{\circ}$ Jornada Nacional del Maní; 2011. pp. 58-59

[33] Astiz Gassó M, Wojsko A. Evaluación in vitro de fungicidas curasemillas para el control químico del carbón del maní. 26 Jornada Nacional de Maní. General Cabrera, Córdoba; 2013. pp. 60-62

[34] Accendere M, Zuza M, Kearney M, Alcalde M, Peralta V, Rago A. Dispersion predial de teliosporas de Thecaphora frezii. $32^{\circ}$ Jornada Nacional de Maní. 21 de septiembre. General Cabrera, Córdoba; 2017. 62 p

[35] Marraro Acuña F, Haro RJ. Carbón del maní (Thecaphora frezii): su incidencia en rotaciones de cultivo. $26^{\circ}$ Jornada Nacional de Maní. General Cabrera. Córdoba; 2011. pp. 28-30

[36] Oddino C, March G, Marinelli A, Rago A, Conforto C, García J, Cazón LI, Vargas Gil S. Control de carbón del maní. Informe técnico de la Fundación Maní Argentino. Campaña 2010/11; 2011. 25 p

[37] Paredes JA, Cazón LI, Osella A, Peralta V, Alcalde M, Kearney MI, Zuza MS, Rago AM, Oddino C. Relevamiento regional del carbón del maní y estimación de pérdidas producidas por la enfermedad. 31 Jornada Nacional de Maní. 22 de septiembre. General Cabrera, Córdoba; 2016. pp. 53-54

[38] Capello G, Dignani D. Control químico del carbón del maní y cuantificacion de la perdida de rendimiento en grano utilizando como medida valores de incidencia. $30^{\circ}$ Jornada Nacional del Maní. General Cabrera, Córdoba; 2015. pp. 75-76

[39] Marraro Acuña F, Wiemer A, Cosa M. Carbón del maní bajo la lupa, anatomía de la infección. $27^{\circ}$ Jornada Nacional del Maní. General Cabrera, Córdoba; 2012. pp. 52-54

[40] Cazón LI, Conforto C, Fernandez F, Paredes JA, Rago AM. Molecular detection of Thecaphora frezii in peanut (Arachis hypogaea L.) seeds. Journal of Plant Pathology. 2016;98(2):327-330

[41] Cazón LI. Detección molecular de Thecaphora frezii Carranza \& Lindquist en semillas de maní Arachis hypogae [tesis]. Córdoba, Argentina: Universidad Nacional de Córdoba; 2015 
[42] Cazón LI, Paredes JA, Bisonard EM, Rago AM. Detección y cuantificación de teliosporas de Thecaphora frezii en semillas de maní usando PCR en Tiempo Real. 31 ${ }^{\circ}$ Jornada Nacional de Maní. 22 de septiembre. General Cabrera, Córdoba; 2016. 56 p

[43] Marraro Acuña F, Mazzini P, Morello L, Zazzetti M. Evaluación de cultivares de maní frente al carbón. 24 Jornada Nacional de Maní. General Cabrera. Córdoba; 2009. pp. 21-22

[44] Marinelli A, March G, Oddino C, Garcia J, Rago A, Zuza M. El carbón del maní de 1995 a 2010 de enfermedad emergente a enfermedad endémica y epidémica. $25^{\circ}$ Jornada Nacional del Maní. General Cabrera, Córdoba; 2010. pp. 28-30

[45] Cignetti M, Baldessari J, Marraro Acuña F, Mazzini P. Evaluación multianual de cultivares de maní frente al carbón (Thecaphora frezii). $25^{\circ}$ Jornada Nacional del Maní. General Cabrera, Córdoba; 2010. pp. 20-22

[46] Farías A, Baldessari J, Marraro AF, Mazzini PH. Evaluación de cultivares de maní alto-oleico frente al carbón (Thecaphora frezzi). 26 Jornada Nacional del Maní. General Cabrera, Córdoba; 2011. pp. 20-22

[47] Cazón LI, Bisonard EM, Conforto C, March G, Rago A. Estrategias para el manejo del carbón del maní. $28^{\circ}$ Jornada Nacional del Maní. General Cabrera, Córdoba; 2013. pp. 28-30

[48] Paredes JA, Cazón LI, Bisonard EM, Rago AM. Efecto de fungicidas con carboxamidas en el control de Thecaphora frezii. $30^{\circ}$ Jornada Nacional de Maní. General Cabrera, Córdoba; 2015b. pp. 65-66

[49] Zuza M, Rago A, Kearney M, Rappa R, Peralta V, Alcalde M, Peiretti G, Ibañez M, Paredes J, Cazón LI. Comportamiento de genotipos de maní frente al carbón (Thecaphora frezii). IV Congreso Argentino de Fitopatología. Mendoza, Argentina; 2017. 454 p

[50] Faustinelli PC, Bressano M, Soave SJ, Oddino C, De Blas F, Soave JH, Buteler MI. Carbón del maní: desarrollo de marcadores moleculares para asistir al mejoramiento genético. $30^{\circ}$ Jornada Nacional de Maní. General Cabrera, Córdoba; 2015. pp. 95-96

[51] Rao NK, Reddy LJ, Bramel PJ. Potential of wild species for genetic enhancement of some semi-arid food crops. Genetic Resources and Crop Evolution. 2003;50(7):707-721

[52] Oddino C, Soave J, Soave S, Moresi A, Bianco C, Buteler M, Faustinelli P, Torre D. Avances geneticos en la tolerancia a carbón del maní causado por Thecaphora frezii. $28^{\circ}$ Jornada Nacional del Maní. General Cabrera, Córdoba; 2013. pp. 28-30

[53] Fundación Maní Argentino. Manejo de enfermedades fúngicas del maní. Informe final; 2010. $48 \mathrm{p}$

[54] Spinazzé C, Marraro Acuña F. Estudio del efecto de la ubicación de las esporas sobre la intensidad del carbón del maní. 30 Jornada Nacional de Maní. General Cabrera, Córdoba; 2010. pp. 4-6

[55] Cignetti MI, Marraro Acuña F, Mazzini PH. Influencia de la labranza sobre la intensidad del carbón del maní. 25 Jornada Nacional del Maní. General Cabrera, Córdoba; 2010. pp. 12-14 
[56] Kearney MI, Cerioni GA, Morla FD, Bonvilliani D, Tello RD, Avellaneda M, Díaz Menaches J, Picco F, Segovia P. Avances en el control de carbón (Thecaphora frezzii) con la aplicación de fosfitos en el cultivo de maní. $30^{\circ}$ Jornada Nacional de Maní. General Cabrera, Córdoba; 2015. pp. 83-84

[57] Morla F, Kearney M, Cerioni G, Pichetti L, Bonvilliani D, Tello D, Avellaneda M, Díaz Menaches J, Picco F, Segovia P. 15 Jornadas Fitosanitarias Argentinas; 2015. 109 p

[58] Pastor NA, Ganuza M, Reynoso MM, Folguera J, Rovera M, Torres AM. Bioproducto a base de Trichoderma controla el carbón de maní y aumenta de rendimiento del cultivo. $30^{\circ}$ Jornada Nacional de Maní. General Cabrera, Córdoba; 2015. pp. 81-82

[59] Ganuza MR, Pastor NA, Folguera J, Andrés J, Reynoso MM, Rovera M, Torres AM. Perspectivas de aplicación de bioformulado de Trichoderma harzianum ITEM 3636 para el control del carbón del maní. 31 Jornada Nacional de Maní. 22 de septiembre. General Cabrera, Córdoba; 2016. pp. 28-30

[60] Paredes JA, Cazón LI, Bisonard EM, Oddino C, Rago AM. Efecto de ingredientes activos fungicidas sobre la intensidad del carbón del maní. $30^{\circ}$ Jornada Nacional de Maní. General Cabrera, Córdoba; 2015. p. 68-69

[61] Paredes JA, Cazón LI, Bisonard EM, Rago AM. Blanco de aplicación de diferentes fungicidas para el manejo del carbón del maní (Thecaphora frezii). $15^{\circ}$ Jornadas fitosanitarias Argentinas; 2015. $119 \mathrm{p}$

[62] Paredes JA, Cazón LI, Bisonard EM, Edwards Molina JP, Rago AM. Uso de fungicidas para el control de Thecaphora frezii en ensayos a campo. $15^{\circ}$ Jornadas fitosanitarias Argentinas; 2015. $235 \mathrm{p}$

[63] Augusto J, Brenneman TB, Culbreath AK, Sumner P. Night spraying peanut fungicides I. Extended fungicide residual and integrated disease management. Plant Disease. 2010a; 04:676-682

[64] Augusto J, Brenneman TB, Culbreath AK, Sumner P. Night spraying peanut fungicides II. Application timings and spray deposition in the lower canopy. Plant Disease. 2010b;94:683-689

[65] Boote KJ. Growth stages of peanut. Peanut Science. 1982;9(1):35-39 